\title{
STRATEGI BERTAHAN HIDUP PERAJIN GERABAH TRADISIONAL
}

\section{J oan Hesti Gita Purwasih ${ }^{1^{*}}$, Mahendra Wijaya ${ }^{2}$, Drajat Tri Kartono ${ }^{3}$}

Faculty of Social Science, Universitas Negeri Malang, Jawa Timur, Indonesia.

${ }^{23}$ Faculty of Social and Political Science, Universitas Sebelas Maret, Jawa Tengah, Indonesia.

\section{ARTICLE INFORMATION}

Submitted : 02 May 2019

Review : 19 August 2019

Accepted : 01 December 2019

Available online: December 2019

KEYWORDS

Gerabah tradisional; Strategi adaptasi; Ekologi budaya; Julian Steward

\section{CORRESPONDENCE}

*E-mail:joan.hesti.fis@um.ac.id

\section{A. PENDAHULUAN}

$\mathrm{G}$ erabah tradisional merupakan warisan budaya yang patut dilestarikan. Meskipun demikian, perajin gerabah tradisional kini semakin menurun. Wilayah yang mengalami penurunan perajin tersebut dapat di temukan di beberapa perdesaan Indonesia, misalnya di Desa Tojan (Provinsi Bali), perajin yang tersisa tidak lebih dari lima orang (Mustofa, 2017). Kondisi tersebut juga dialami di Desa Paseban, Kabupaten Klaten. Berdasarkan data peneliti jumlah perajin terus menglami penurunan. Pada tahun 2014 perajin di desa ini ada 77 kepala keluarga, Pada tahun 2015 menurun menjadi 71, pada tahun 2016 sejumlah 63, dan terus menurun. Khusus di Dukuh Dolon di 2018 jumlah perajin kini tidak mencapai lebih dari 20 kepala keluarga (Purwasih \& Hadi, 2017). Padahal, membuat gerabah merupakan salah satu kearifan lokal yang ada di Desa Paseban (Ardika, 2014).

\section{A B S T R A C T}

The decreased number of traditional earthenware craftsmen occurs due to three main factors: basic material, worker, and consumer. Some craftsmen instead prefer staying so that they should adapt to the existing condition. Nevertheless, in fact, some of them prefer stopping from being craftsmen now. Departing from this reality, the author tried to raise earthenware craftsmen's adapting strategy to survive until today. The author employed a qualitative method. The phenomenological research was chosen with interview and observation being the techniques of collecting data. The result of research generally showed a variety of products produced aiming to document cultural heritage threatened to be extinct. Meanwhile, as the analysis technique, the author borrowed Julian Steward's cultural-ecological perspective to explain the data found. Data analysis was conducted using an interactive technique of analysis. Considering the findings of the research, the craftsmen took a different surviving strategy today compared with that in the past. This change was effected by such constraints as basic material, consumer, and human resources. Julian Steward's culturalecological concept seemed to be insufficient. Therefore, natural resources as the main basic material of industrial society should be understood more complexly to a more macro level.

Sebenarnya tidak jauh dari Desa Paseban terdapat pula Desa Melikan yang juga menghasilkan gerabah. Berbeda dengan Desa Paseban (Dukuh Dolon), Desa Melikan mampu mengembangkan usaha dan produk gerabah yang lebih modern meskipun keduanya samasama pernah mengalami krisis akibat gempa di tahun 2006. Selain pengaruh bencana, secara umum keduanya mengalami kendala yang sama, yaitu sumber daya alam yang semakin terbatas (Hastuti, 2012) . Akan tetapi, karena jenis produk yang dihasilkan berbeda, produk-produk Gerabah Desa Melikan masih banyak diminati oleh peziarah Makam Wali Sunan Tembayat (Ismail, 2016). Sementara itu, meskipun dekat dengan lokasi tersebut, gerabah Dukuh Dolon tetap sepi peminat.

Beberapa daerah lain juga sempat mengalami kondisi yang sama. Meskipun demikian, kondisi ini dapat disikapi dengan strategi lain yaitu pengembangan objek wisata seperti yang diterapkan pada Desa Gebangsari (Kabupaten Kebumen). Desa ini mengembangkan konsep eduwisata dan kini perajin yang kembali aktif 
dalam pembuatan gerabah dapat meningkat (Syarif Hidayat, 2018). Selain itu, gerabah di Kecamatan Plered, Kabupaten Purwakarta mampu berkembang melalui penerapan One Village One Product (OVOP) (Triharini, Larasati, \& Susanto, 2014).

Upaya membangkitkan kerajinan gerabah di beberapa daerah tersebut menunjukkan transformasi industri yang maju. Pada kasus tersebut pemberdayaan dapat memberikan dampak positif. Akan tetapi, kenyataannya pemberdayaan justru tidak berhasil memberikan dampak positif bagi masyarakat Dukuh Dolon. Pemberdayaan sudah banyak masuk, terutama pasca gempa 2006. Upaya pemberdayaan tersebut banyak dilakukan oleh LSM dan lembaga pendidikan tinggi. Akan tetapi, hingga kini pemberdayaan-pemberdayaan tersebut kandas di tengah jalan. Pemberdayaan tersebut banyak berupaya mengajarkan cara-cara baru dalam mengolah dan mengelola gerabah. Misalnya, dengan mengajarkan pembuatan gerabah hias. Akan tetapi, kenyataanya inovasi tersebut tidak berhasil. Perajin hingga kini tetap bertahan menghasilkan gerabah tradisional seperti keren, wajan, kwali, blengker, dan kendil. Sementara itu, konsumen jenis produk tersebut tidaklah banyak di era saat modern saat ini. Akibatnya, pemasukan yang diperoleh pun tidak memadai.

Perajin hingga kini terus bertahan meskipun penghasilan yang diperoleh tidak bisa memenuhi kebutuhan hidup mereka secara layak. Berdasarkan data lapangan, biaya produksi perajin nyatanya tidak sebanding dengan hasil penjualan. Adapun bahan baku yang sulit diperoleh di antaranya tanah liat dan bahan bakar. Tanah liat hitam dengan kualitas baik harus diperoleh dari sawah sewa yang lokasinya jauh dari desa. Sementara itu, setiap tahunnya harga sewa sawah terus meningkat di tengah menurunnya jumlah perajin yang ikut serta dalam sewa tanah. Bahan baku pembakaran seperti kayu bakar, jerami, dan daun kering juga semakin sulit diperoleh. Penyebab utamanya ialah menurunnya pemasok bahan baku tersebut. Selain itu, anggota keluarga perajin terutama laki-laki dalam tidak lagi bersedia mencari bahan baku tersebut di luar desa.

Perajin tidak dapat meningkatkan harga barang yang diproduksinya secara signifikan. Penyebab pertama dipengaruhi oleh semakin sedikitnya pengepul yang bersedia menadah hasil produksi perajin. Faktor kedua tentunya dipengaruhi oleh semakin sedikitnya peminat/ konsumen gerabah. Gerabah tradisional untuk keperluan rumah tangga banyak digunakan oleh masyarakat perdesaan, yaitu mereka yang masih menggunakan kayu bakar untuk memasak. Tentunya jumlah pengguna tersebut kini semakin terbatas. Penurunan ini sangat perajin rasakan sejak terjadi konversi bahan bakar dan pemerataan LPG $3 \mathrm{~kg}$.
Berdasarkan paparan realitas sosial tersebut, peneliti mencoba menggali strategi bertahan hidup yang dilakukan perajin. Penelitian serupa mengenai strategi bertahan hidup perajin gerabah sebelumnya sudah pernah dilakukan di Desa Kademangan Jombang secara kuantitatif (Firdiyanti, 2016). Secara umum cara bertahan yang ditemukan penelitian tersebut hanya menggambarkan fenomena yang terjadi dalam satu waktu dan data kuantitatif. Akan tetapi, melalui penelitian ini penggambaran strategi bertahan hidup perajin pada masa lalu dan masa sekarang peneliti sajikan secara komprehensif. Selain itu, analisis ekologi budaya digunakan sebagai salah satu perspektif yang menunjukkan bahwa manusia dan alam tidak dapat dipisahkan.

\section{B. METODE}

$\mathrm{P}$ enelitian ini dilakukan di Dukuh Dolon, Desa Paseban, Kabupaten Klaten, Jawa Tengah. Dukuh Dolon merupakan bagian dari Desa Paseban. Dukuh Dolon terdiri atas RW 07 dan RW 08. Lokasi Dukuh Dolon relatif jauh yaitu sekitar 45-60 menit dari pusat Kota Klaten menggunakan kendaraan bermotor. Lokasi dapat ditempuh menggunakan kendaraan umum (bus) atau kendaraan bermotor melalui jalan WediCawas, yaitu arah melewati dua objek wisata religi Gowa Maria Marginingsih dan Makam Sunan Pandanaran.

Adapun jenis penelitian yang diterapkan yaitu kualitatif dengan pendekatan fenomenologi. Fenomenologi cocok dipilih untuk mengungkapkan pengalaman individu ataupun kelompok (Creswell, 2014), Penelitian ini merupakan penelitian lanjutan dari penelitian sebelumnya yaitu tahun 2016 dan data diperbaharui pada tahun 2018. Teknik pengumpulan data dilakukan melalui wawancara dan observasi. Adapun unit analisis dan narasumber penelitian ini ialah keluarga yang masih bertahan membuat gerabah hingga tahun 2018. Teknik validitas data dilakukan melalui triangulasi sumber. Analisis data dilakukan melalui tahapan pengumpulan data, reduksi, data, dan penyajian data yang disajikan secara runtut dan mengalir.

\section{HASIL DAN PEMBAHASAN}

\section{Mengenal Industri Kerajinan Gerabah Dukuh Dolon}

$\mathrm{D}$ ukuh Dolon pernah menjadi pusat industri yang besar dan menjadi pemasok gerabah berbagai daerah di Jawa Tengah. Kondisi ini dirasakan sebelum hingga sekitar tahun 1950-an, saat hampir setiap kepala keluarga menjadi penghasil gerabah yang mandiri. Sisa-sisa masa keemasan ini masih dapat ditemukan pada kondisi lingkungan rumah 
penduduk. Berdasarkan hasil pengamatan selama penelitian, rumah penduduk Dukuh Dolon yang masih membuat gerabah pada umumnya memiliki ciri berikut:

a. Sekitar rumah terdapat sisa-sisa pecahan gerabah.

b. Memiliki tempat penyimpanan kayu bakar dan daun-dun kering.

c. Memiliki halaman/sisa bangunan yang cukup luas untuk menjemur dan membakar gerabah

Kondisi tersebut kini hanya dapat ditemukan pada beberapa rumah. Sebagian besar rumah warga kini tidak lagi memiliki halaman luas, sisasisa pecahan gerabah, dan tempat penyimpanan kayu. Semuanya berubah seiring berjalannya waktu, adapun faktor utamanya ialah tidak ada lagi generasi penerus pembuat gerabah dalam masing-masing keluarga. Kondisi ini menjadi kasus yang unik dan berbeda dengan kasus industri gerabah lain yang berhasil mempertahankan budaya membuat gerabah dari satu generasi ke generasi, seperti di Jepara (Triyanto, 2015).

Generasi anak-anak perajin sebagian besar beralih pekerjaan ke sektor lain, sekolah ke jenjang lebih tinggi, dan bekerja di luar desa. Adapun sektor yang banyak dipilih yaitu sebagai kuli bangunan, pekerja pabrik, dan wirausaha. Peralihan pekerjaan yang dilakukan oleh anakanak perajin ini jusru dirasa cukup positif dalam membantu perekonomian keluarga. Oleh karena itu, keluarga yang dahulu membuat gerabah kini perlahan tidak lagi meneruskan usaha turuntemurun tersebut. Secara fisik perubahan tampak pada kondisi tempat tinggal, yaitu rumah tidak lagi memiliki halaman untuk membuat dan membakar gerabah. Halaman rumah tersebut berlahan menjadi hunian permanen yang digunakan oleh anak-anak perajin.

Peralihan pekerjaan yang dilakukan generasi anak dalam satu unit keluarga ini menyebabkan hambatan yang sangat berarti terhadap industri gerabah Dukuh Dolon. Tidak ada lagi anak lakilaki yang membantu orang tua mengumpulkan bahan baku, serta tidak ada lagi anak perempuan yang membantu membuat gerabah. Karakteristik industri yang bersifat otonom dalam unit keluarga inti tersebut menyebabkan kesulitan dalam melakukan produksi.

Sampai pada titik ini, sebagian besar perajin yang bertahan sudah lanjut usia. Selain itu, sebagian besar perajin mayoritas berstatus janda. Pembuatan gerabah di Dukuh Dolon sangat bergantung pada perempuan. Tidak ada laki-laki yang bisa membuat gerabah. Peran lakilaki dalam industri gerabah bukanlah membuat, melainkan membantu menggosok, menjemur, dan membakar. Oleh karena itu, kelangsungan industri gerabah keluarga sangat bertumpu pada keterampilan perempuan.

Perempuan pembuat gerabah di Duku Dolon terampil dalam membuat peralatan rumah tangga yang tahan api. Teknik pembuatan gerabah yang digunakanpun sedikit berbeda. Alat putar dikombinasikan dengan teknik bentukan manual menggunakan tangan. Produk ini berbeda dengan gerabah desa lain. Ada banyak teknik dalam membuat gerabah misalnya di wilayah Melikan. Meskipun kedua lokasi berdekatan hanya berjarak sekitar satu kilo meter, penguasaan teknik putaran miring seperti yang ada di Melikan tidak ditemukan di Dukuh Dolon. Perajin gerabah Dukuh dolon juga tidak menerapkan teknik pembuatan gerabah yang dilakukan dengan cara tinggang perajin seperti di Lombok Timur. Pada teknik ini perajin yang melakukan putaran mengelilingi gerabah (Dewi, Suartini, \& Rediasa, 2016).

Produk gerabah Dukuh Dolon tidak menggunakan tanah liat merah, tetapi tanah liat hitam yang dicampur dengan pasir kali. Tanah liat jenis ini cukup sulit dicari, karena tanah liat hitam berkualitas tidak lagi dengan mudah ditemukan di sekitar desa. Tanah liat hitam pun harus memiliki kualitas baik karena tidak boleh memiliki campuran kerikil. Tanah liat, diperoleh dengan cara sewa bersama dengan perajin Dukuh Kebondalem. Sementara itu, pasir yang diproleh warga dari sekitar sungai akan cukup sulit ditemukan jika hujan deras memenuhi sungai.

Warna merah bata juga menjadi ciri khas produk gerabah Dukuh Dolon. Warna merah gerabah Dukuh Dolon diperoleh dari pelapisan tanah merah yang diambil di sekitar Makam Sunan Pandanaran dan dicampur dengan air. Pewarnaan alami ini menunjukkan adanya kearifan lokal yang dipertahankan dari satu generasi ke generasi. Adapun proses pewarnaan ini dilakukan setelah proses pembakaran pertama dan proses pembakaran kedua. Tanah merah dari sekitaran Makam Sunan Pandanaran dipercaya memiliki kualitas baik dan dapat membawa keberkahan bagi perajin.

Gerabah dibuat dari pencampuran bahan baku tanah liat dan pasir, beberapa perajin menggabungkannya melalui proses tradisional, yaitu dengan cara diijak menggunakan kaki. Proses ini membutuhkan tenaga dan waktu yang cukup lama. Akan tetapi, melalui proses tersebutlah perajin dapat menentukan tingkat ketercukupan antarkomposisi bahan. Akan tetapi, ada juga sebagian kecil perajin yang menggunakan alat pencampur modern, yaitu molen. Akan tetapi, ini lebih banyak membutuhkan biaya karena harus mengeluarkan upah tenaga pencampur dan bahan bakar mesin. Setelah tercampur rata perajin akan menyimpan bahan baku pada bagian rumah yang dibentuk menyerupai kolam dan ditutupi dengan plastik untuk menjaga kelembaban.

Pada proses pembuatan alat-alat yang digunakan pun masih tradisional. Ada prebot, kerik, tatap dan watu, serta batu kali seperti pada gambar-gambar berikut. 


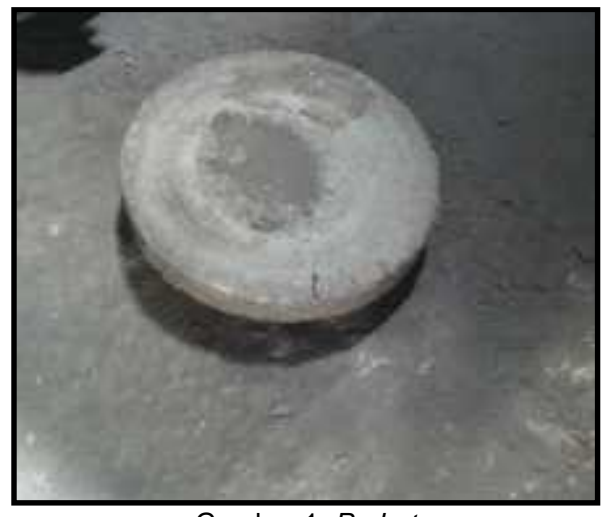

Gambar 1. Prebot

Sumber: dokumentasi peneliti

Prebot merupakan alat yang digunakan perajin untuk membuat kerangka gerabah. Alat dahulu terbuat dari kayu dan porosnya ditanam di lantai rumah yang masih beralaskan tanah. Akan tetapi, pasca gempa 2006 alat-alat perajin banyak mengalami kerusakan. Oleh karena itu, prebot dibuat menggunakan bahan lain seperti semen. Alat ini digunakan dengan cara diputar.

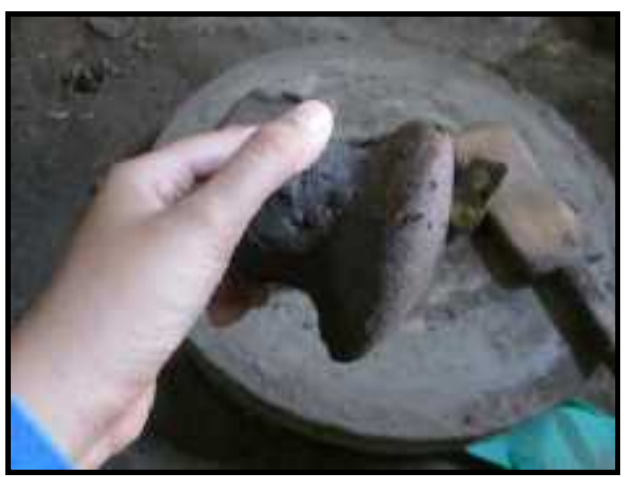

Gambar 2. Watu

Sumber: dokumentasi peneliti

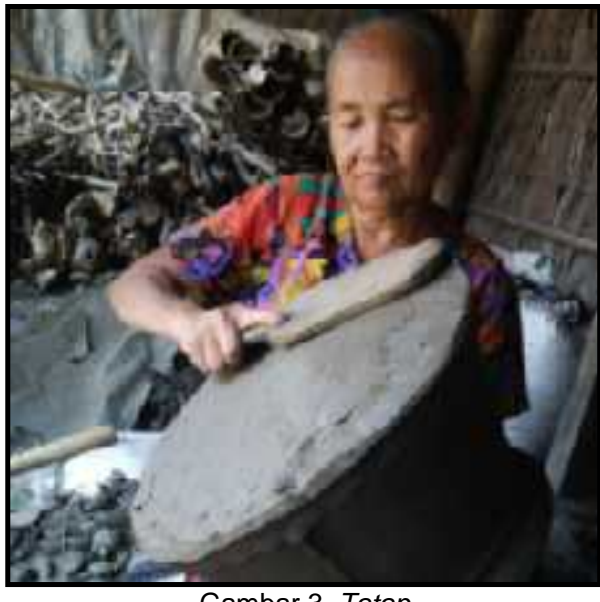

Gambar 3. Tatap

Sumber: dokumentasi peneliti

Tatap dan watu digunakan bersamaan untuk membentuk dan meratakan permukaan gerabah. Tatap terbuat dari kayu, sementara watu terbuat dari tanah liat yang memiliki permukaan cembung. Kedua alat ini dipukul bersamaan dari arah yang berbeda, yaitu bagian dalam dan luar.

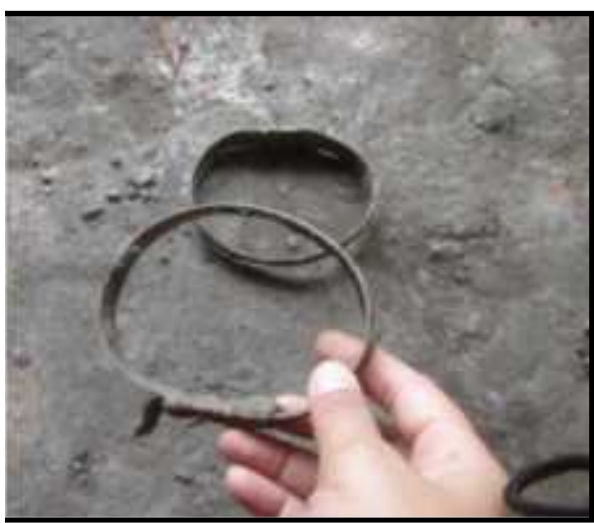

Gambar 4. Kerik

Sumber: dokumentasi peneliti

Kerik merupakan lingkaran seperti gelang yang terbuat dari bambu untuk menipiskan gerabah. Perajin menggoreskan kerik pada permukaan gerabah agar terkikis dan terus menjadi tipis. Gerabah yang sudah dibentuk dijemur setengah kering dihaluskan menggunakan batu kali yang memiliki permukaan halus. Selanjutnya gerabah kembali dijemur untuk kemudian dibakar. Pada proses pembakaran gerabah disusun melingkar menyerupai tumpukan gunung berongga dengan kayu dan pecahan gerabah sebagai alas pondasi pembakaran. Celah pada rongga tumpukan menjadi saluran untuk memasukkan kayu secara perlahan. Selain kayu sela-sela dan permukaan gerabah diberi jerami untuk membantu proses pembakaran. Gerabah pun biasaya mulai dibakar pada subuh dini hari seperti gambar berikut.

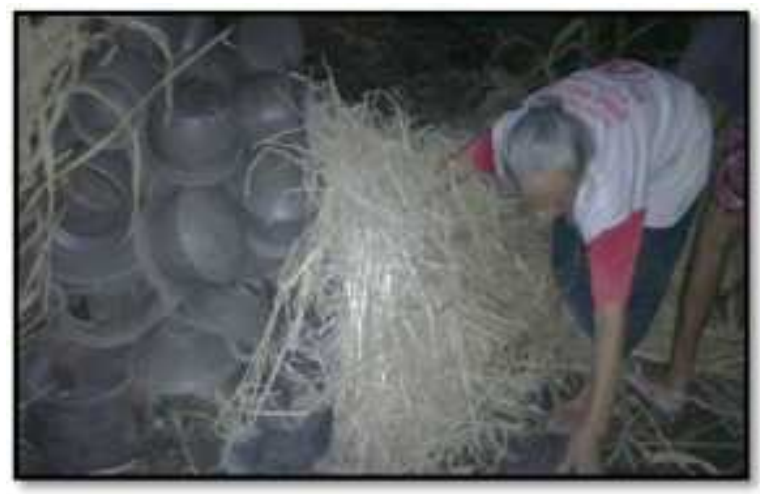

Gambar 5. Poses menata pembakaran Sumber: dokumentasi peneliti

Hasil pembakaran menghasilkan berbagai produk peralatan rumah tangga. Sayangnya produk tersebut kini semakin jarang digunakan. Bahkan warisan kerajinan tradisional tersebut kini semakin jarang dikenal masyarakat. Adapun produk-produk yang dihasilkan perajin sebagai berikut. 


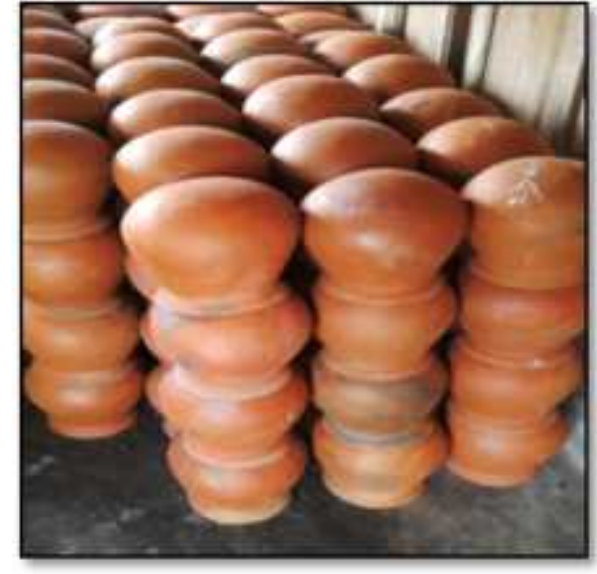

Gambar 5. Kendil

Sumber: dokumentasi peneliti

Kendil bisa dimanfaatkan untuk memasak jamu, sayur, bubur, dan memasak nasi sebelum dikukus.

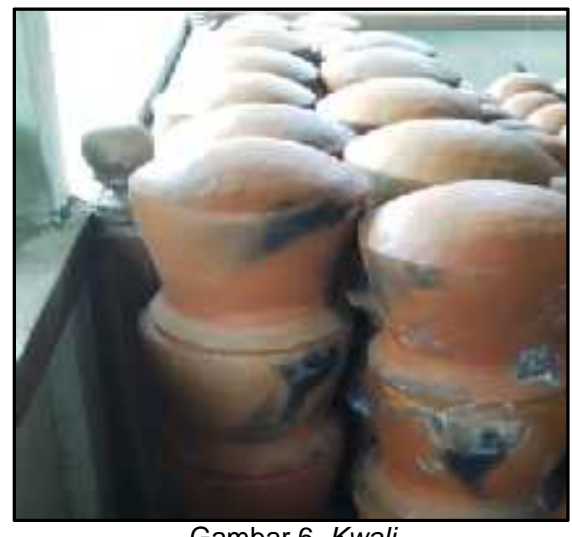

Gambar 6. Kwali

Sumber: dokumentasi peneliti

Kwali banyak dimanfaatkan oleh penjual soto kwali khas Kabupaten Klaten. Selain itu, dahulu pada umumnya alat ini dimanfaatkan untuk mengukus nasi. Alat ini dikolaborasikan dengan anyaman bambu yang berbentuk kerucut dan berfungsi sebagai penyaring.

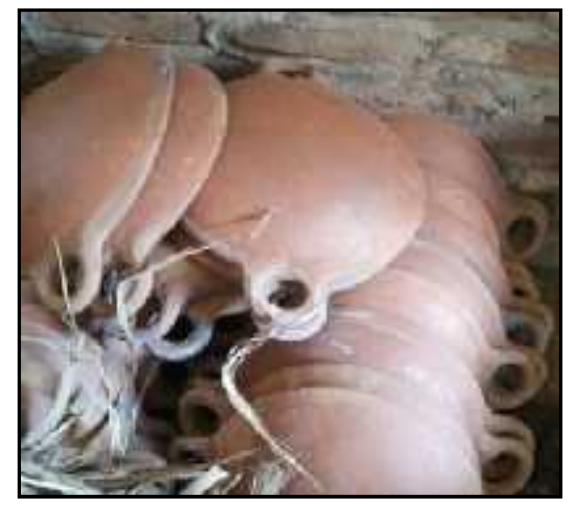

Gambar 7. Wajan

Wajan tanah liat ini digunakan untuk menumis dan mengoreng. Ada wajan yang berukuran kecil dan besar. Ada pula wajan yang dibentuk lebih cekung.

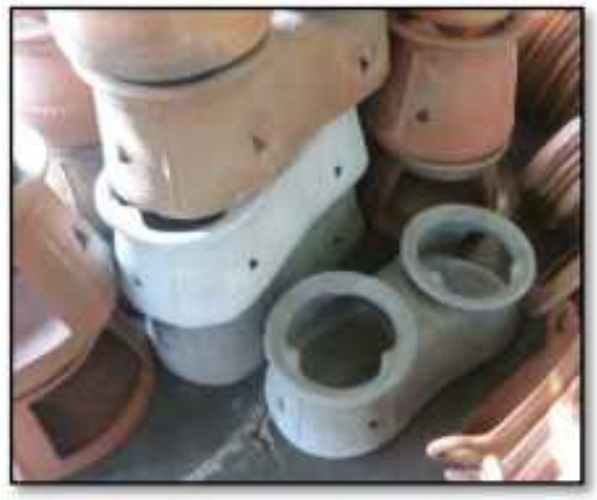

Gambar 8. Keren

Sumber: dokumentasi penelit

Keren atau tungku ini masih banyak dimanfaatkan masyarakat, misalnya digunakan para pedagang sate, bakmi jawa, dan soto yang ada di sekitar kabupaten Klaten. Keren ini ada yang didesain untuk pembakaran menggunakan arang dan kayu bakar.

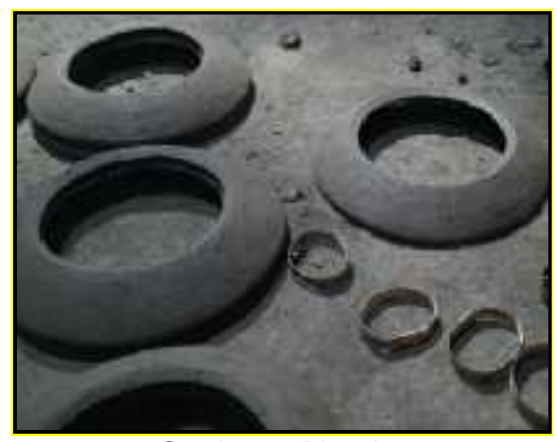

Gambar 8. Blengker

Sumber: dokumentasi peneliti

Blengker berfungsi sebagai tatakan wajan atau kwali. Blengker kini sudah semakin jarang digunakan. Kondisi ini dapat diamati dari sedikitnya perajin yang memproduksi jenis barang ini. Produksi jenis produk ini pun semakin sedikit karena sulit laku di pasaran Meskipun dijual dengan harga murah, sekitar lima ribu rupiah per biji nya, jenis produk ini kini jarang diminati masyarakat.

Berdasarkan pemaparan jenis produk yang dihasilkan Dukuh Dolon, semua peralatan rumah tangga ini merupakan warisan budaya leluhur yang kini semakin sedikit dan terancam punah. Peralatan rumah tangga ini menjadi saksi peradaban masyarakat tradisional yang kini mulai diabaikan.

\section{Kendala Industri Gerabah Tradisional Masa Kini}

Setiap jenis industri memiliki tantangan dan kendala tersendiri. Pada umumnya kendala tersebut selalu berkaitan dengan faktor-faktor produksi. Dalam temuan penelitian ini, klasifikasi kendala peneliti sajikan dalam tiga kategori yaitu konsumen, bahan baku, tenaga, dan distribusi. 
Adapun pemaparan kendala yang dialami industri gerabah saat ini peneliti sajikan sebagai berikut.

\section{a. Konsumen}

Penurunan konsumen merupakan menjadi tantangan utama dalam setiap sektor industri termasuk gerabah tradisional. Gerabah tradisional tidak lagi ditemukan pada dapur-dapur rumah tangga masyarakat. Kondisi ini terjadi siring transformasi bahan bakar dan alat-alam memasak. Pada umumnya kayu bakar menjadi pasangan alat-alat masak gerabah ini. Akan tetapi, kini masyarakat sudah semakin jarang menggunakan kayu bakar/arang sebagai bahan bakar memasak.

Sebenarnya gerabah bisa digunakan sebagai peralatan memasak masa kini yang menggunakan bahan bakar gas. Panas yang diserap gerabah lebih tahan lama. Meskipun demikian, banyak konsumen berdalih gerabah tidak lebih awet dan membutuhkan waktu panas yang lebih dibandingkan alat masak berbahan alumunium atau sejenisnya. Oleh karena itu, minat konsumen masa kini tidaklah luas.

\section{b. Bahan baku}

Pada pembahasa sebelumnya sudah dijelaskan mengenai bahan baku yang dibutuhkan untuk membuat gerabah. Adapun kendalah utama bahan baku yang dialami perajin Dukuh Dolon yaitu pada tanah liat dan bahan pembakaran.

Tanah liat semakin jauh dari desa dan jumlah perajin yang ikut patungan dalam menyewa tanah semakin sedikit. Implikasi pertama, perajin harus menambah biaya untuk mengeluarkan jasa tenaga pengabil tanah. Kedua, perajin semakin mahal menanggung biaya sewa tanah bersama. Hal ini dilakukan seiring tidak memadainya tanah liat di wilayah desa sendiri. Industri masyarakat dalam membuat gerabah sudah berlangsung hampir satu abad, jauh sejak generasi sebelumnya. Oleh karena itu, tanah liat dengan kualitas memadai sudah semakin sulit. Kondisi ini juga dipengaruhi oleh pembangunan dan jumlah penduduk di desa. Lahan-lahan yang ada sudah banyak bergeser sebagai pemukiman penduduk.

\section{c. Tenaga}

Tenaga kerja awalnya dilakukan oleh keluaga inti. Akan tetapi, sebagian besar kini hanya dilakukan oleh generasi tua (ayah dan ibu), bahkan sebagian besar kini hanya dilakukan oleh ibu (lansia berstatus janda). Pada kondisi ini perempuan yang sudah lanjut lansia menunjukkan adanya kemampuan untuk bisa mandiri dan memenuhi ekonomi keluarganya. Kondisi ini pada umumnya ditemukan di wilayah perdesaan, yaitu perempuan menjadi ujung tombak ekonomi keluarga meskipun pada ranah domestik (Meliza, Iskandar, \& Soemarwoto, 2019).

Akan tetapi, tidak semuanya bisa dilakukan perajin perempuan. Kenyataannya terdapat bagian pekerjaan yang membutuhkan tenaga ekstra sehingga membutuhkana biaya yang ekstra pula yaitu untuk tenaga mengambil bahan baku tanah, sebagian membutuhkan tenaga pencampur tanah, serta tenaga penggosok gerabah. Kondisi ini pada umumnya dilakukan oleh perajin yang sudah tidak memiliki anggota keluarga laki-laki. Kegiatan produksi bertumpu pada perempuan. Pembuatan gerabah hanya boleh dilakukan oleh perempuan. Kondisi ini merupakan budaya yang banyak ditemukan pada sektor industri gerabah. Misalnya pada kerajinan gerabah di Desa Banyumulek, Lombok Barat. Perempuan menjadi tenaga kerja utama dalam pembuatan gerabah (Vibriyanti, 2015).

\section{d. Distribusi}

Kendala distribusi berkaitan dengan bagian pemasaran gerabah. Dahulu sebagian besar perajin menjual gerabah melalui peran ayah. Ayah dapat menjual gerabah berhari-hari ke luar Kabupaten Klaten dengan jumlah gerabah yang banyak. Akan tetapi, cara ini sudah tidak dilakukan sejak lama yaitu ketika tenaga ayah mulai senja dan konsumen pun menurun.

Sebagian besar perajin kemudian banyak beralih menggunakan jasa bakul dan pengepul. Bakul merupakan pemembeli gerabah dalam jumlah besar yang berasal dari luar desa. Bakul kemudian akan menjual kembali gerabah ke luar desa. Sementara itu, pengepul merupakan warga desa setempat yang bersedia membeli gerabah perajin dalam jumlah besar. Pengepul kemudian menjual kembali gerabah kepada bakul luar desa ataupun menjual gerabah di rumah masingmasing.

Saat ini bakul gerabah tradisional semakin sedikit. Hanya bakul dengan permintaan produk tertentu yang masih membutuhkan gerabah. Misalnya, kwali, keren, dan kendil. Produk tersebut masih digunakan oleh penjual-penjual makanan tradisional. Begitu pula dengan pengepul yang ada di desa. Pengepul semakin enggan menghimpun produk perajin di rumah mereka dalam jumlah besar karena penjualan yang semakin macet.

Akibatnya, perajin semakin sulit menyalurkan barang dagangannya. Di tengah pembengkakan bahan baku, produk yang dihasilkan justru melemah. Pendapatan perajin semakin sedikit, sementara modal yang dibutuhkan semakin besar.

\section{Alasan Tetap Bertahan}

Masih ada perajin yang bertahan membuat gerabah meskipun hasil yang diperoleh tidak sebanding dengan pengeluaran modal produksi. Mereka sebagian besar ialah para perajin yang kini sudah memasuki usia lansia.

Sebagian perajin gerabah terus bertahan hanya untuk mengisi waktu luang. Anak-anak mereka sudah cukup mampu memenuhi kebutuhan keluarga dengan bekerja di sektor lain 
yang lebih menghasilkan. Maka tidak heran jika faktor ekonomi tidak menjadi hambatan dalam membuat gerabah. Pada umumnya ikondisi ni dialami oleh keluarga yang mampu meyekolahkan anak-anaknya ke jenjang pendidikan tinggi. Perajin dengan karakteristik keluarga seperti ini pada umumnya dahulu merupakan produsen gerabah kelas atas. Mereka memiliki modal besar dan memiliki jaringan pasar yang luas di luar desa.

Meskipun demikian, masih terdapat pula perajin yang bertahan karena tidak memiliki keterampilan lain untuk menyambung hidup keluarga. Perajin percaya meskipun hasil yang diperoleh tidak sebanding, gerabah akan selalu memberikan keberkahan. Sebagian tidak mau berpangku tangan mengandalkan bantuan dari anak-anak mereka. Pada umumnya pandangan tersebut dialami oleh perajin yang usianya sudah lansia sementara anak-anak mereka memiliki kondisi ekonomi menegah ke bawah. Hal ini pada umumnya ditemukan pada karakteristik industri keluarga menengah yang sejak dahulu memiliki modal kecil dan tidak memiliki jaringan pasar yang luas.

Kondisi karakteristik industri keluarga menengah ke bawah tersebut juga menimbulkan konsekuensi lain, yaitu dengan berhenti memproduksi gerabah. Ini dialami sebagian perajin yang belum terlalu tua. Gerabah ditinggalkan karena menyadari bahwa kebutuhan keluarga tidak bisa dipenuhi jika terus bertahan. Golongan ini pada umumnya masih memiliki anak yang masih menjadi tanggungan di rumah.

Gerabah sebenarnya disadari perajin sebagai warisan leluhur yang harus dilestarikan. Akan tetapi, realitas kehidupan berkata lain. Gerabah kini tidak mampu mencukupi kebutuhan hidup mereka. Oleh karena itu, mereka tidak bisa berbuat banyak apabila generasi muda di desa tidak lagi berminat untuk meneruskan keterampilan tersebut. Orientasi perajin kini telah berubah, gerabah memang cukup berharga untuk mereka teruskan tetapi tidak untuk anakanak mereka. Hal inilah yang menjadi ancaman terbesar hilangnya warisan keterampilan budaya membuat peralatan rumah tangga tradisional yang tahan api di Dukuh Dolon terus berlangsung.

\section{Strategi Bertahan Hidup}

\section{a. Strategi Masa Lalu}

Strategi bertahan hidup perajin berkaitan dengan sistem produksi gerabah. Dahulu perajin memiliki siklus pembuatan gerabah yang relatif stabil, yaitu dua minggu untuk proses pembuatan dan dua minggu kemudian untuk mengumpulkan bahan baku serta menjual gerabah. Pendapatan yang diperoleh dalam satu kali pembakaran digunakan untuk bertahan hidup satu siklus. Pada masa itu, penghasilan yang diperoleh dari membakar gerabah masih cukup memadai untuk menyisihkan modal bahan baku terlebih dahulu barulah kebutuhan hidup. Pada umumnya siklus ini dilakukan oleh keluarga dengan tingkat produksi tinggi.

Pada sebagian perajin dengan tingkat produksi menengah ke bawah, pinjaman modal dari bakul/pengepul menjadi salah satu cara untuk menunjang kebutuhan modal dan kehidupan sehari-hari. Pinajam diberikan dengan jaminan sejumlah gerabah yang nantinya akan diambil ketika masa pembakaran usai.

Pada situasi ini, masyarakat memililiki tatanan sistem kegiatan ekonomi yang mapan. Konsumsi, produksi dan distribusi dilakukan karena adanya keseimbangan. Kemapanan ini dipengaruhi oleh ketersediaan sumber daya alam, sumber daya manusia, dan kondisi pasar yang masih memadai. Kondisi ini sekaligus menunjukkan adanya interaksi sosial yang mapan antara budaya, manusia, dan lingkungan dalam indikator ekologi lingkungan.

\section{b. Strategi Masa Kini}

Melihat berbagai tantangan gerabah tradisional masa kini, strategi bertahan hidup perajin pun mengalami perubahan. Kondisi itu dipengaruhi oleh siklus pembakaran yang semakin tidak menentu. Setiap unit industri pembuat gerabah kini membuat gerabah berdasarkan cepat lambatnya barang yang mampu dibeli pengepul/bakul. Kondisi ini terus berlanjut di tengah jumlah konsumen yang semakin memudar.

Kondisi ini semakin diperparah dengan jumlah pengepul/bakul yang semakin menurun. Bahkan sudah ada beberapa bakul yang tidak lagi aktif mengambil gerabah. Sementara pengepul di sekitar desa tidak berani lagi membeli gerabah perajin dengan jumlah banyak. Meskipun demikian, sebagian bakul tetap bersedia memberikan pinjaman tentunya dengan jaminan gerabah perajin. Rasa kekeluargaan dan ketetanggan menjadi unsur yang masih diperhitungkan pada cara-cara ini.

Pada akhirnya, hutang menjadi jalan terakhir yang terus dipertahankan perajin. Hutang melalui jaminan gerabah diandalkan perajin kepada pengepul dan bakul. Ketika gerabah telah selesai dibakar dan disetorkan perajinpun sudah tidak menerima imbalannya karena harus membayar hutang. Perajin pun hidup dalam keadaan sangat sederhana, dalam kondisi miskin dan mengandalkan bantuan beras raskin dari pemerintah.

Tidak jarang sebagian perajin memilih beralih pekerjaan karena merasa gerabah sudah tidak bisa mencukupi kebutuhan hidupnya. Misalnya menjadi buruh/tenaga lepas di sektor industri lain yang mulai berkembang di desa yaitu industri pembuatan kerupuk rambak. Pada akhirnya beralih pekerjaan merupakan strategi akhir yang dipilih oleh perajin karena bertahan membuat gerabah sudah tidak lagi memungkinkan bagi mereka. 


\section{c. Strategi Bertahan Hidup Perajin Gerabah dari Perspektif Ekologi Budaya}

Berdasarkan pemaparan yang sudah dibahas dapat diketahui bahwa manusia dan lingkungan tidak dapat dipisahkan dan saling memengaruhi. Kondisi inilah yang digagas oleh Julian Steward melalui ekologi budaya. Budaya merupakan hasil dari adaptasi terhadap linngkungan. Artinya, aktivitas manusia dalam memenuhi kebutuhan hidupnya merupakan salah satu wujud budaya sehingga proses tersebut pula nantinya akan memengaruhi lingkungan. (Gunn, 1980).

Menurut Julian Steward cara terbaik untuk mempelajari antropologi pada penekanan ekologi budaya ialah dengan mengkaji tekonologi yang digunakan (technoenviromental relationship), cara yang digunakan (exploitation relationship), dan efeknya terhadap lingkungan (effects of technological - exploitation) (Steward, 1955). Berangkat dari tiga komponen tersebut, peneliti menemukan bahwa strategi bertahan hidup perajin gerabah pada penelitian ini dipengaruhi oleh ketiga unsur tersebut.

Meninjau kondisi strategi bertahan masa lalu, industri gerabah dalam unit keluarga masih cukup memadai karena sumber daya yang ada, teknologi, dan cara yang digunakan masih memadai. Artinya, efek pengolahan terhadap lingkungan belum dirasakan. Misalnya, tidak terjadi kelangkaan bahan baku.

Sementara itu, pada masa-masa selanjutnya, sistem produksi perajin mengalami perubahan. Perubahan ini disebabkan oleh berbagai faktor, di antaranya sumber daya alam yang semakin tidak memadai. Industri tradisional pada umumnya hanya memanfaatkan sumber daya alam yang ada di lingkungan sekitarnya. Ketika sumber daya alam di lingkungan sekitarnya sudah tidak memadai maka sistem produksi dan budaya pun berubah (Steward, 1977). Cara-cara baru dengan memanfaatkan tenaga luar dimanfaatkan. Artinya, jika salah satu faktor produksi berupa bahan baku memudar maka industri tradisional tersebutpun akan terganggu. Sayangnya, kondisi ini tidak bisa dikontrol sendiri oleh produsen.

\section{KESIMPULAN}

andangan Julian Steward mengenai ekologi budaya membantu kita memahami strategi manusia mempertahankan hidup- nya. Akan tetapi, tawaran tiga komponen utama dalam memahami ekologi budaya Julian Steward ternyata tidaklah cukup. Manusia hidup dalam sistem yang kompleks dan berhubungan satu sama lain. Terutama jika analisis kondisi ekologi budaya diletakkan pada kehidupan masyarakat yang sudah mengarah pada kegiatan industri.

Komponen konsumen, sebagai pengguna hasil budaya pembuatan gerabah menjadi salah satu pengaruh utama keberlangsungan pembuatan gerabah di Desa Paseban. Selain itu, sebagai industri, pembuatan gerabahn membutuhkan tidak hanya satu bahan baku. Artinya, kelangkaan satu bahan baku di sekitar lingkungan masyarakat memengaruhi perubahan cara produksi masyarakat. Pada kondisi ini ekologi budaya harus dikembangkan dengan melihat ekosistem sumber daya alam yang lebih makro dan kolmpleks.

Saran yang direkomendasikan untuk menyikapi kondisi ini ialah dengan melakukan komodifikasi budaya. Budaya lama dihidupkan kembali dengan cara-cara baru dan bentuk produk yang baru (Irianto, 2016). Oleh karena itu, dibutuhkan integrasi teknologi dan sumber daya manusia yang memadai di dalamnya. Gerabah tahan api ini bisa dipromosikan sebagai peralatan dapur yang kekinian dan memiliki variasi fungsi. Misalnya, gerabah tahan api ini bisa digunakan untuk menyajikan makanan yang menggunakan unsur hot plate di beberapa restoran. Gerabah Desa Paseban ini mampu menyerap panas tahan lama sehingga cocok untuk digunakan. Selain itu, bisa dimanfaatkan untuk menyajikan makanan yang sidatnya dipanaskan terus menerus menggunakan api. Misalnya, untuk jenis bubur, sup panas, dan suki.

\section{E. UCAPAN TERIMAKASIH}

$\mathrm{T}$ erimakasih kepada Universitas Sebelas Maret dan Universitas Negeri Malang atas kesempatan yang sudah diberikan kepada kami untuk menulis artikel jurnal ini dengan baik. Meskipun demikian, ide ini tidak mungkin diwujudkan tanpa adanya perhatian dari pemerintah dan stakeholder yang peduli terhadap warisan budaya lokal. Oleh karena itu, kerja sama yang baik sangat dibutuhkan.

\section{DAFTAR PUSTAKA}

Ardika, F. (2014). Relasi Antara Kearidan Lokal Masyarakat Desa Paseban dengan Interaksi Terhadap Sumber Daya Hutan. Universitas Gadjah Mada. Retrieved from http://etd.repository.ugm.ac.id/index.php?mod=penelitian_detail\&sub=PenelitianDetail\&act=v iew\&typ=html\&buku_id=70229 
Creswell, J. W. (2014). Penelitian Kualitatif dan Desain Riset, Memilih di Antara Lima Pendekatan. (S. Z. Qudsy, Ed.) (3rd ed.). Yogyakarta: Pustaka Pelajar.

Dewi, N. K., Suartini, L., \& Rediasa, I. N. (2016). Kerajinan Gerabah Tinggang Di Desa Banyumulek, Kecamatan Kediri, Lombok Barat. Jurnal Pendidikan Seni Rupa Undiksha.

Firdiyanti, B. (2016). Strategi Bertahan Hidup Pengrajin Gerabah Sebagai Upaya Pemenuhan Kebutuhan di Desa Kademangan Kecamatan Mojoagung Kabupaten Jombang. Swara Bhumi.

Gunn, M. C. (1980). Cultural Ecology: A Brief Overview.

Hastuti, I. (2012). Perkembangan usaha industri kerajinan gerabah, faktor yang mempengaruhi, dan strategi pemberdayaanya pada masyarakat di desa melikan kecamatan wedi kabupaten klaten. Benefit Jurnal Manajemen Dan Bisnis.

Irianto, A. M. (2016). Komodifikasi Budaya Di Era Ekonomi Global Terhadap Kearifan Lokal: Studi Kasus Eksistensi Industri Pariwisata dan Kesenian Tradisional di Jawa Tengah. Jurnal THEOLOGIA. https://doi.org/10.21580/teo.2016.27.1.935

Ismail, A. (2016). Ziarah Ke Makam Wali: Fenomena Tradisional di Zaman Modern. Al-Qalam. https://doi.org/10.31969/alq.v19i2.156

Meliza, R., Iskandar, B. S., \& Soemarwoto, R. S. (2019). Aspek Ekonomi Pada Kehidupan Perempuan Lanjut Usia: Studi Etnografi di Desa Demuk, Kecamatan Pucanglaban, Kabupaten Tulungagung. Jurnal Antropologi: Isu-Isu Sosial Budaya. https://doi.org/10.25077/ jantro.v21.n1.p11-21.2019

Mustofa, A. (2017, August). Tragis, Kurang Menarik, Jumlah Perajin Gerabah Kian Menurun. Radarbali.Jawapost.Com. Retrieved from https://rada rbali.jawapos.com/read/2017/08/21/8686/tragis-kurang-menarik-jumlah-perajin-gerabahkian-menurun

Purwasih, J. H. G., \& Hadi, N. (2017). The Failure of Regeneration Traditional Pottery Handicraft Process of Pottery Industry. In 2nd International Conference on Sociology Education (Vol. 2, pp. 578-583). Scitepress. https://doi.org/10.5220/0007113512181223

Steward, J. H. (1955). 2 The Concept and Method of Cultural Ecology. In Theory of Culture Change: The Methodology of Multilinear Evolution.

Steward, J. H. (1977). The Concept and Method of Cultural Ecology. Evolution and Ecology: Essays on Social Transformation. Urbana: University of Illinois Press.

syarif hidayat. (2018, November). Tawarkan Konsep Eduwisata, Kampung Gerabah Gebangsari Kian Banyak Dikunjungi. Sorot.Co. Retrieved from http://kebumen.sorot.co/berita-4748-tawarkankonsep-eduwisata-kampung-gerabah-gebangsari-kian-banyak-dikunjungi.html

Triharini, M., Larasati, D., \& Susanto, R. (2014). Journal of visual art and design. Journal of Visual Art and Design.

Triyanto. (2015). Perkeramikan mayong lor jepara: hasil enkulturasi dalam keluarga komunitas perajin. Imajinasi: Jurnal Seni.

Vibriyanti, D. (2015). Peran Kaum Perempuan Dalam Industri Kerajian Gerabah Di Desa Banyumulek, Lombok Barat, Nusa Tenggara Barat. Jurnal Antropologi: Isu-Isu Sosial Budaya, 17(2), 117129. https://doi.org/10.25077/jantro.v17.n2.p117-129.2015 